\title{
The Dialectic Method: A Critical and Postmodern Alternative to the Scientific Method
}

\author{
Phillip Dybicz \\ Loretta Pyles
}

\begin{abstract}
This paper introduces Hans-Georg Gadamer's dialectic method and elaborates upon its application to social work inquiry. Its strengths lie in its ability to uncover socially constructed truths, to explain human behavior in a non-deterministic manner that emphasizes personal agency and empowerment, and to foster a consciousnessraising process that leads to praxis. This makes it ideally suited for knowledge gathering by practitioners in the field who seek to apply postmodern practice approaches such as the strengths perspective, solution-building therapy, and narrative therapy. Examples are given of its application to both micro and macro practice concerns.
\end{abstract}

Keywords: Empowerment; hermeneutics; research methods; critical theory

\section{INTRODUCTION}

When assisting individuals with their life issues or working with communities to promote development, social workers engage in a process of inquiry that informs interventions and actions. In order to have confidence in the knowledge acquired from an inquiry, one must follow a systematic method for gathering the knowledge relevant to one's concerns. In its drive towards professionalization in the early 1900s, social work embraced the scientific method as its model for inquiry (Leighninger, 2000; Trattner, 1999). Consequently, traditional social work practice has become an exercise in hypothesis testing as reflected in its early embrace of the medical model (Leighninger, 1987; Specht \& Courtney, 1995) and its current evolution into a problem-solving model for practice (Blundo, 2006; De Jong \& Berg, 2008; Turner \& Jaco, 1996). Knowledge is gathered, an assessment is made, and then an intervention delivered based upon the assessment (Gambrill, 2006; Hepworth, Rooney, \& Larsen, 2009; Johnson \& Yanca, 2009).

Since Abraham's Flexner's infamous speech (1915) critiquing social work for lacking a unique body of knowledge, over the past 100 years social work academics have amassed an impressive quantity of scientific knowledge. Thus, one aspect of social work education involves fostering the ability of a student to consume this knowledge and apply it to practice. The role that scientific knowledge can and should play in social work practice is not the topic of this paper. ${ }^{1}$ Social work education also seeks to educate students (through research methods courses) about a method of inquiry through which to gather knowledge and seek truth. Drawing from the field of psychology, our profession embraced the scientific method and, in the 1960s, began to elaborate a dream of the social worker as being a scientist-practitioner (Wakefield \& Kirk, 1996; Witkin, 1996). In the 1970s, Fischer $(1973 ; 1981)$ attempted to fuel this dream by offering single-system

Phillip Dybicz, Ph.D., is an Assistant Professor in the Department of Social Welfare at Keimyung University in Daegu, South Korea. Loretta Pyles, Ph.D., is an Associate Professor of Social Welfare and Director, Community and Public Service Program, State University of New York at Albany. The present research has been supported by the Bisa Research Grant of Keimyung University in 2011.

Copyright (C) 2011 Advances in Social Work Vol. 12 No. 2 (Fall 2011), 301-317 
design as a means for practitioners to apply the scientific method as a form of inquiry. Popular current approaches are to teach program evaluation and evidence-based practice (Grinnell \& Unrau, 2011; Royse, Thyer, \& Padgett, 2009). Yet while the ideal of the scientist-practitioner remains strong in social work research textbooks, this dream has never reached fruition in the field. In a survey of 7,000 BSW and MSW social work practitioners (Teare \& Sheafor 1995), respondents listed competencies in research inquiry as having minimal importance to their work.

Yet to look within mainstream textbooks, alternatives to the scientific method appear quite limited. For example, Rubin and Babbie (2005) list the following as ways of knowing that are alternatives to the scientific method: tradition, authority, common sense, and popular media. Most social work research textbooks (Drake \& Jonson-Reid, 2007; Engel \& Schutt, 2010; Grinnell \& Unrau, 2011) advance the notion that when gathering knowledge and seeking truth, the scientific method is the only legitimate game in town. To do otherwise, one falls prey to ignorance. However, there in fact exist alternative systems of rigorous inquiry to the scientific method-one need only to look to the humanist traditions of history, philosophy, and literary studies as proof that systematic investigation can be accomplished without following the scientific method. When the term "research" is interpreted to mean "a systematic method of knowledge gathering for determining truth" as opposed to simply being interpreted as "the scientific method", other possible forms of inquiry arise. For example, when we reflect upon the type of knowledge gathering done by practitioners as they delve into clients' lives, it seems clear that practitioners might benefit from a thorough knowledge of the comparative methodthe methodological inquiry that drives historical research and investigative journalism.

In this paper, the authors introduce another alternative: the dialectic method. In Western thought, the dialectic method itself originated during the time of Socrates around 400 BCE. It is the methodology that currently fuels critical theory, feminist epistemology, and various forms of postmodernist thought. Its ability to bring to light contradictions and drive a consciousness-raising process among its inquirers makes it ideally suited for postmodern and critical social work practice approaches. Besides the importance of embracing contradictions, social work scholars of dialectics have noted the importance of dialectical thought in contributing towards the social construction of identities and the interconnectedness relevant to social work practice (Leonard, 1997; Tsang, 2000). The authors begin with a discussion of the history of the evolution of the dialectic method as a way to elaborate its basic principles and how they guide inquiry. Next, Gadamer's (1960/1999) model for dialectic inquiry will be elaborated with attention given to its use as a model for social work inquiry. Lastly, examples will be given of these principles at work in guiding postmodern and critical micro and macro practice approaches.

\section{HISTORY OF DIALECTIC METHOD ${ }^{2}$}

\section{Socrates}

"I only know that I know nothing." This simple phrase uttered by Socrates encapsulates the core of his wisdom, and forms the roots from which the dialectic method has grown. Plato's writings on Socrates illustrating the dialectic method in this pure form 
(known as the early dialogues) always ended with a non-answer. In one such dialogue, Socrates enters into a dialogue with Euthyphro concerning the meaning of piety. At the beginning of the conversation, Euthyphro is quite certain he knows what piety is; Socrates adopts the position that he does not know. By the end of the dialogue, Socrates is still not certain of one true definition for piety, yet also, he has moved Euthyphro to this same conclusion. This is an example of a successful use of the dialectic method because the purpose of Socrates' inquiry is to break through one's hubris that one "knows" and thus free the mind to critically examine alternate possibilities. As McAvoy (1999) notes, "It is the bite or sting that wakes us from our complacency, arouses us to excellence, to learn and discover and inquire” (p. 19).

In social work literature, Anderson and Goolishian (1992) are noted for first elaborating the merits of such a not-knowing approach when entering a dialogue with clients. The social worker takes on the role of Socrates as the not-knowing inquirer, while the client is in the role of Euthyphro. The "bite or sting" serves to awaken clients to question oppressive devaluations of their identity and thus consider more empowering identity conclusions. More will be elaborated upon this later in the application to social work section.

\section{Hegel and Marx (the beginnings of critical theory)}

Hegel's writings represent a modern reformulation of the Socratic dialectic method and the roots of the critical tradition. The centerpiece of Hegel's philosophy was human freedom, or agency, and specifically the unique ability of human consciousness to be aware of itself and reflect on its future (Blackburn, 1994). In contrast to the Newtonian project, dialectics arises from phenomenology's stance that "all 'things' are actually processes, that these processes are in constant motion, or development, and that this development is driven by the tension created by two interrelated opposites acting in contradiction with each other" (Au, 2007, p. 2). These processes are known as phenomena, and are conceived as comprising an existence plus an essence.

Hegel (1830/1991) postulated that logic and history follow a dialectical pattern, what Fichte (Kaufman, 1988) later called the "thesis-antithesis-synthesis." ${ }^{3}$ Hegel posited that this dialectic was fundamentally constituted in the realm of ideas or spirit. Marx's innovation was to "turn Hegel on his head" by arguing that the dialectic operated in the material realm, namely through production, i.e. economics. Philosophical materialism, as opposed to Hegel's philosophical idealism, means that our understanding of a phenomenon's essence stems from our interactions with the material world and not vice versa. ${ }^{4}$ For Marx, dialectics is not just an epistemological or ontological theory, but it necessarily involves praxis. Thus, for social work practice, dialectical inquiry is a not just a way to generate knowledge; it is also a key component of social work practice itself.

The Marxian dialectic-with its focus upon praxis and the analysis of power relations-provided the framework of inquiry from which critical theory was born. Beginning in the first half of the 20th century, critical theory represented the application of the Marxian dialectic by various German philosophers and social theorists, loosely known as the Frankfurt school, to critique existing social practices by shedding light on 
the oppression arising from contradictions within the capitalist economy (Jay, 1973/1996). As elaborated by Horkheimer (1982), critical theory aims toward a specific purpose, "to liberate human beings from the circumstances that enslave them" (p. 244).

\section{Husserl and Heidegger (the beginnings of a postmodern dialectic)}

Husserl (1913/1982) labeled both Hegel's and Marx's stance on phenomenology as the "natural standpoint": the essence of the phenomenon lies within the phenomenon itself, and accurate perception is needed in order to reveal it. By contrast, Husserl (1913/1982) advanced the notion that the essence of the phenomenon lies within human consciousness.

Heidegger (1927/1962) advanced Husserl's standpoint even further by arguing that the essence of a phenomenon lies within language, and hence, culture. Thus under Heidegger's definition, the phenomenological understanding of reality becomes an endeavor aimed at accurate interpretation rather than accurate perception. Consequently, his approach gained the label of hermeneutic phenomenology. With its stance that reality arises from accurate interpretation, a Heideggerian phenomenological investigation opens the door for the recognition of the existence of multiple realities, thus putting it in alignment with social constructionism - a theory that holds much affinity with postmodern social work practices.

This latest evolution of phenomenological thought, represented by Heidegger, laid the foundation once again for a re-formulation of dialectical inquiry (elaborated by Gadamer below). This reformulation enabled postmodern theorists to embrace critical theory as an approach of its own, moving it off its narrow economic base of examining oppression arising from class relations to more broadly examining the oppression visited upon individuals from cultural societal narratives defining gendered relations, racial relations, and relations of various sexual orientations, to name but a few (Kaufman, 2003; Lindlof \& Taylor, 2002).

Within critical theory based in postmodern thought, the area where this enslavement occurs is in the construction of identity that de-values the individual or community. So for example, social work scholars have spoken to the dynamic of how a diagnostic label comes to dominate the client's identity within the helping relationship (De Jong \& Berg, 2008; Saleebey, 2006b). The consciousness-raising process that arises from a dialectical inquiry serves to liberate individuals through insights that empower them to reassert their own power in defining who they are and who they wish to be (via the recognition that many possible realities exist). Praxis (understanding that necessarily translates into action) occurs as individuals find that they can no longer act in ways that support the oppressive societal narratives. Furthermore, this same praxis causes them to confront material structures of oppression in society spawned by these dominant societal narratives.

\section{Gadamer}

Building upon the hermeneutic insights of Heidegger, Gadamer (1960/1999), in his seminal work Truth and Method, offers up a new formulation of the dialectic method: 
thesis-antithesis-fusion of horizons. His dialectic approach has been labeled philosophical hermeneutics. ${ }^{6}$ Gadamer's project involves elaborating a dialectic method to be used for encountering historical and literary texts, but more broadly it speaks to a dialogue that leads to the understanding of reality. Gadamer's dialectic method has its application to social work inquiry via the stance of viewing humans' lived experiences as a behavioral text (White \& Epston, 1990). Crucial to Gadamer's (1960/1999) elaboration are the following concepts: bias, world, horizon, and fusion of horizons.

Bias: When the process of capturing the reality of an object (as in science) or a phenomenon (as in phenomenology) is seen as requiring accurate perception, bias is seen as an obstacle to this process. However, with Heidegger's (1927/1962) move of viewing the essence of a phenomenon as something granted to it by language, bias represents this granting of essence, and thus contributes to the construction of reality. This is because when one encounters the existence of a phenomenon, one must use language when seeking to understand it. Within this formulation, bias has a neutral connotation as it is an integral component of reality; Gadamer (1960/1999) re-labels "bias" as "foreunderstanding". This fore-understanding is a product of one's historical-social consciousness-one's unique encounter with the culture (societal, familial, work, etc.) of one's time.

World: Only human beings have a world (Gadamer, 1960/1999). All other living things have a habitat. Since human beings possess a consciousness, and thus by necessity seek to understand their habitat (via language) rather than simply interact with it, humans rise above their habitat and live within a world (a phenomenon comprised of existence plus essence). One's historical-cultural consciousness constructs one's world.

Thus, bias plays an active part in this construction as it is necessary for navigating one's world. Take for example an encounter with a stop sign. When one encounters a stop sign, one brings a fore-understanding of how to interpret the stop sign. If one had to interpret the stop sign anew each time one encountered it, along with everything else in one's world, one would not be able to function effectively.

Horizon: Gadamer (1960/1999) uses the term "horizon" to describe the outer boundaries of one's historical-cultural consciousness, the outer limits of one's understanding:

We started by saying that a hermeneutical situation is determined by prejudices that we bring with us. They constitute, then, the horizon of a particular present, for they represent that beyond which it is impossible to see (p. 272).

While fore-understanding allows one to easily function in one's world, it is also limiting in that it creates a horizon of understanding beyond which one is not able to conceive of alternative possibilities of being.

Fusion of horizons: Gadamer is quick to point out that one's present horizon of understanding is not a static condition. It is open to change, as is one's historical-cultural consciousness. In fact, a change in one's historical-cultural consciousness is the goal of a dialectical inquiry. This is why it can be described as a consciousness-raising experience. Gadamer (1960/1999) notes the following: 
In fact the horizon of the present is being continually formed, in that we have continually to test all our prejudices. An important part of this testing is the encounter with the past and the understanding of the tradition from which we come.... Understanding, rather, is always the fusion of these horizons which we imagine to exist by themselves (p. 273).

In this passage, Gadamer is speaking about one's encounter with a past historical or literary text. One brings one's own world, one's own horizon of understanding, to the interpretation of the text. But also, one opens up a dialogue with a past world, the horizon of understanding that existed when the text was created. The resulting dialogue results in a fusion of horizons, a constructed reality born from both worlds; a new foreunderstanding is created. As the final step in the dialectical process, this dynamic will be explored in more detail in the following section.

In terms of social work inquiry, people's lived experiences are looked upon as a behavioral text. One's present horizon of understanding constructs a reality for these experiences - a reality that speaks to one's identity. Social work inquiry turns its focus upon those constructed realities that exert an oppressive influence on individuals by undercutting their self worth. A second horizon of understanding is sought that is in opposition to the oppressive constructed reality of concern, and thus serves as a means to question its legitimacy. This opens up a dialogue from which arises the fusion of the two, a constructed reality that no longer operates in an oppressive manner, and thus no longer undercuts the client's self worth.

\section{GADAMER'S DIALECTIC METHOD}

An important feature that distinguishes Gadamer's (1960/1999) dialectic method from that established by Hegel (1830/1991) is that Gadamer returns dialectic inquiry to its Socratic roots by embracing dialogue as its driving force. Hegel places the dialectic inquiry within a monologue, the singular voice of reason drives the inquiry in its attempts to accurately perceive a single reality. Hegel's monologue of reason leads to the inquiry's formulation being that of thesis-antithesis-synthesis. Synthesis represents a single understanding, a single reality that arises from the opposites.

By contrast, Gadamer's (1960/1999) formulation is that of thesis-antithesis-fusion of horizons. This can be further elaborated as thesis (present familiar horizon of understanding)-antithesis (alien horizon of understanding)-fusion of horizons. The antithesis represents an alternative constructed reality, one which serves to question the legitimacy of the constructed reality of the thesis. Such a movement is what begins the consciousness-raising process. The fusion of horizons represents the dialogue that opens up between the thesis and the antithesis, wherein the biases of the thesis are tested and other possible constructed realities explored (for social work, this concerns other articulations of identity). The elaboration that follows will emphasize the affinity Gadamer's (1960/1999) formulation holds for understanding a behavioral text-the lived experiences of persons. 


\section{Thesis (present familiar horizon of understanding)}

Within a social work dialectic inquiry, the social worker plays the role of Socrates. $\mathrm{He}$ or she adopts the stance of "not knowing" and invites the client (individual/family/community) into a dialogue about a topic of vital interest to the client. Thus the beginning of this dialogue will involve the client elaborating his or her understanding of the topic. This understanding is the thesis of the dialectical inquiry. Within various postmodern social work literature (Brubaker \& Wright, 2006; White \& Epston, 1990), this thesis is often described as a dominant or master narrative. When applied to micro practice, this thesis will arise from the presenting problem and focus upon how it acts in an oppressive manner concerning the client's identity conclusions. When applied to macro practice, the thesis will also arise from the presenting problem with the focus this time being upon oppression operating at the structural level in society upon a marginalized group (and the resulting identity conclusion that arises).

The role of Socrates is important here as the client is placed in the position of having to explain this understanding to someone who is "ignorant" and thus does not know. Normally, one's biases, one's fore-understanding, operate at the intuitive level. The process of having to explain one's fore-understanding to someone who is ignorant necessarily moves this fore-understanding from one's intuitive level to one's conscious level of understanding. Once these biases are exposed in one's conscious level of understanding, they can be examined and tested.

Gadamer (1960/1999) views dialectic inquiry as a conversation that relies upon the art of questioning, "Dialectic, as the art of asking questions, proves itself only because the person who knows how to ask questions is able to persist in his [sic] questioning, which involves being able to preserve his orientation towards openness” (p. 330). This is where the expertise of the social worker comes into play. The social worker's expertise is that of a critical consciousness; this allows her or him to step into the role of Socrates and artfully ask questions that preserve the openness of the conversation to other possibilities. In this first phase of the dialectic inquiry-elaborating the thesis-the social worker's critical consciousness directs him or her to explore the various identity conclusions that arise from the client's understanding of the thesis. Mindful of the theory of mimesis (Dybicz, 2010a; Ricoeur 1984-88), he or she knows that a change in client's actions will arise from a change in identity conclusions.

\section{Antithesis (alien horizon of understanding)}

The expertise of the social worker is relied upon even more heavily in this phase of the inquiry. In this phase of the dialectical conversation, the client is called upon to elaborate an understanding that is alien, and contrary to the client's understanding presented in the thesis. The knowledge of these other possibilities arises from the artful questioning by the social worker. Gadamer (1960/1999) notes the following:

... as soon as we accept the priority of the question over the answer, which is the basis of the concept of knowledge. Knowledge always means, precisely, looking at opposites. Its superiority over preconceived opinion consists in the fact that it is able to conceive of possibilities as possibilities (p. 328). 
Gadamer (1960/1999) also notes that a dynamic important for this knowledge to arise is that both parties of the conversation genuinely seek the truth, and thus work together towards this goal:

To conduct a conversation requires first of all that partners to it do not talk at cross purposes.... It requires that one does not try to out-argue the other person, but that one really considers the weight of the other's opinion. Hence, it is an art of testing. But the art of testing is the art of questioning.... A person who possesses the 'art' of questioning is a person who is able to prevent the suppression of questions by the dominant opinion (p. 330).

The dominant opinion referred to above is the thesis, or master narrative. The social worker's expertise brings to the table a critical consciousness that frees him or her from the constraint that a dominant opinion would normally exert. Thus the social worker is free to consider other possibilities of interpreting the behavioral text, hence other possible constructed realities (and the resulting identity conclusions that arise from them).

The antithesis that arises does not come from fore-knowledge on the part of the social worker, as the social worker truly does not know what this will be for the client. The client must elaborate this antithesis, but the client is guided by the artful questioning of the social worker. As the thesis currently represents the client's reality, the artful questioning seeks to invoke the imagination of the client as the vehicle for elaborating the antithesis. For example, one illustration of this process can be seen in solution building therapy (Dejong \& Berg, 2008) with the asking of the miracle question. The miracle question asks the client to imagine life absent the problem. Artful questioning on the part of the social worker encourages the client to slowly but surely elaborate such a picture (and the resulting identity conclusions that arise from it). The assets-based community development (ABCD) approach advocated for by Kretzmann and McKnight (1997) provides another example. The social worker uses an assets assessment as a tool to inspire artful questioning that leads the residents to elaborate a view of their community as an oasis of resources, thus taking ownership of their community's identity in a way that contradicts the previous problem-saturated narrative.

\section{Fusion of Horizons}

Once the thesis and antithesis are clearly elaborated, the dialogue continues between these opposite poles and from within which a new understanding (i.e., a new constructed reality) will arise from the fusion of the two. Each has something to contribute to this fusion. The thesis contributes the phenomenal objects (i.e., lived experiences comprising the behavioral text) that are of vital interest to the client. This vital interest is what initiated the inquiry process and thus serves to frame it. Some of these lived experiences are what Abbott (2002) describes as a constituent event (of a narrative or text). A constituent event is an event that is necessary to the narrative for it to maintain the integrity of its topic. For example, a pregnant teenager who is struggling over this issue cannot simple ignore the fact that she is pregnant: her pregnancy is a constituent event. In addition, Abbott (2002) states that narratives are also comprised of supplementary events. While not necessary to maintain the integrity of the topic, supplementary events 
contribute towards the theme that arises from the narrative (i.e. identity conclusions from a behavioral text). As many of the identity conclusions from the thesis undercut the client's self worth, many of the thesis' supplementary events are discarded as inappropriate.

A well elaborated antithesis contributes the identity conclusions that are lifeenhancing, and thus of vital interest to the client. While these identity conclusions arise from a horizon of understanding based within the client's imagination, they can be made applicable to the client's present behavioral text. This is done in two ways. First, they can act as a lens in which to discover heretofore ignored supplementary events in the client's behavioral text which support these life-enhancing identity conclusions. Second, in being clearly elaborated as a firm ideal to which to aspire, they serve to motivate future actions on the part of the client. It is human imagination which allows us to create hopes and dreams. These future actions will be new supplementary and constituent events added to the client's behavioral text. Again, these will be events that support these life-enhancing identity conclusions.

As the conversation unfolds, eventually a truth arises from the fusion of these horizons of understanding. As we are speaking to constructed realities, this will be a poetic truth, or what Bruner (1986) refers to as verisimilitude. Yet it will be a truth that demands recognition all the same. Gadamer (1960/1999) describes this in the following manner:

The unique and continuing relevance of the Platonic dialogues is due to this art of strengthening, for in the process what is said is continually transformed into the uttermost possibilities of its rightness and truth and overcomes all opposing argument which seeks to limit its validity.... Whoever wants to know something cannot just leave it a matter of mere opinion.... It is always the speaker who is challenged until the truth of what is under discussion finally emerges.... What emerges in its truth is the logos, which is neither mine nor yours and hence so far transcends the subjective opinions of the partners to the dialogue that even the person leading the conversation remains ignorant (p. 331).

The relativism inherent in postmodern thought allows for the acceptance of multiple realities (multiple valid interpretations of the behavioral text). Yet, once a dialectic inquiry is begun, a particular truth will arise from the context driving the inquiry that best serves the vital interests of the engaged parties.

\section{APPLICATION TO SOCIAL WORK}

\section{Micro Practice}

Through the therapeutic conversation, social work is able to take Gadamer's (1960/1999) notion of dialogue and give it life in its pure form: following the model of Socrates, two parties (social worker and client, where the client can be an individual or a family) engage in a dialogue as equals, ${ }^{7}$ collaborating together to find truth. In the postmodern context, this truth is one of "multiple realities", or in other words, the verisimilitude of a social construction. The strengths perspective (Saleebey, 2006a), 
solution building therapy (Dejong \& Berg, 2008), and narrative therapy (White, 2007) are three prominent postmodern approaches that embrace the notion that the client is the expert, that dialogue should arise from a collaboration of equals, and that social constructions speak to the client's identity. This makes each highly amenable to a knowledge gathering process driven by the dialectic method.

It should be noted that with the focus of this article being the elaboration of the dialectic method - a heady project in and of itself-for ease of understanding, a deliberate choice is made to keep the reference to narrative therapy, solution-building therapy, and the strengths perspective at this very broad and general level: they all spring from postmodern thought (e.g., all embrace social constructionism, collaboration, and a focus upon articulating identity). And hence, the argument is made that the dialectic method can be used effectively with each approach. We do not seek to favor one approach over another.

Upon first engagement with a client, each of these approaches privileges the client's understanding of the presenting life issue. By adopting a not-knowing stance, the social worker seeks to artfully ask questions that encourage the client to clearly and consciously "map the influence of the problem" (White \& Epston, 1990, p. 42) and thus obtain "the client's frame of reference" (De Jong \& Berg, 2008, p. 55). This description represents the thesis - the master narrative (i.e., bias) under which the client is currently operating. Furthermore, questions are posed that speak to the articulation of the client's identity arising from this thesis.

Next, the social worker poses questions that lead to the formulation of the antithesis: the client's image of life absent any hindrances from the problem. An appeal is made to the client's imagination to create such an image. The miracle question (De Jong \& Berg, 2008), externalization of the problem (White \& Epston, 1990), and a client's ultimate dream or goal (Rapp \& Goscha, 2006) are all examples of how this appeal is made. These techniques are used to artfully guide questions that speak to a new, life-enhancing articulation of the client's identity. This alternative articulation of the client's identity marks the beginning of the consciousness-raising process.

Lastly, the social worker poses questions that seek some type of fusion between these two horizons of understanding (thesis and antithesis). Constituent events from the thesis are retained (i.e., events stemming from the presenting problem), while the antithesis' articulation of identity spawns questions that seek previously ignored strengths (Rapp \& Goscha, 2006), exceptions (De Jong \& Berg, 2008), and unique outcomes (White \& Epston, 1990) to serve as supplementary events in the client's narrative-all of which emphasize the client's personal agency in creating the event. The understanding arising from this fusion (and the resulting articulation of the client's identity) leads to praxis: the client's actions begin to change so that they reflect this new articulation of identity and in the process create a pathway towards successful amelioration of the problem, oftentimes in dramatic fashion. Consciousness-raising allows clients to realize that there are many possible articulations of their identity, and that they have a strong voice in that articulation. 


\section{Macro Practice}

For macro practice, the dialectic method offers a way to understand and confront the workings of power in society, power that leads to oppression. For this reason, employing a Marxian dialectic is still a vital and valid approach, as its materialism directly confronts material forms of oppression. Indeed, Saul Alinsky (1971), a classical icon of community organizing, advocated the use of dialogue to motivate other potential organizers as well as opponents. In Rules for Radicals, Alinsky (1971) offers an example of the Marxian dialectic at work through a conversation with an individual living in slum housing, the goal of which is to create what he terms "friction". Just as important as the recognition of the contradiction - the material injustice-is the awareness of personal agency, group empowerment, and strategies for change. This is exemplified through the idea that if everyone in the building engaged in resistance, a successful outcome might be achieved.

A Gadamerian dialectic inquiry based within hermeneutics confronts the power exerted by societal narratives interpreting reality. Thus it recognizes that societal narratives are not created via a dialogue among equals, as in the Socratic model, but rather arise from unequal social, political, cultural, and gendered relations. Paulo Freire's use of dialectical methods in his popular education and organizing efforts serves as an illustration of Gademerian dialectics operating in macro practice settings (Au, 2007; Freire, 1970; Gadotti, 1994). Freire uses dialogical relationships facilitated through problematizing education by critiquing traditional banking education (where the teacher merely makes deposits in the minds of students). Banking education explains how those with little power in society internalize the master narratives of the oppressor (thesis). Freire worked with illiterate peasants in Brazil teaching them not only to read but using his popular education techniques as a strategy for "conscientization" (antithesis). Eventually, the students/peasants come to imagine how they might go about advocating for changes in their situation given their current constraints and new visions (fusion of horizons).

Both Saleebey's (2006b) application of the strengths perspective to community development and Kretzmann and McKnight's (1997) ABCD approach follow a Gadamerian dialectic mode of inquiry, similar to that illustrated by Friere (1970). When the social worker first enters a troubled community, the first step involves confronting residents' beliefs that their community does not contain any assets or resources (thesis). Like an individual dominated by a diagnostic label, the identity of the community has been dominated by societal narratives that advance a pathologizing "needs-driven dead end" method of community development, diagnosing communities as a host of social problems (e.g., poverty, homelessness, criminal behavior, drug abuse). A strengths or assets assessment is conducted which seeks to identify the resources, assets, and capacities of the community, which, in turn, crafts a life-enhancing picture of the community's identity (antithesis). This sparks the imagination of residents on how to confront community problems (fusion of horizons), by:

helping unleash the power, vision, capacities, and talents within a (self-defined) [my emphasis] community so that the community can strengthen its internal relationships ... strengthen its relationship to outside institutions, associations, 
and organizations ... that allows the community to find its heart, solve its problems, and reach its goals (Saleebey, 2006b, p. 246).

A few other social work scholars have articulated postmodern and critical theories and applied them to issues in macro practice. Pyles' (2009) social work textbook on community organizing provides a framework that draws heavily from critical and postmodern traditions, including social constructionism, critical theory, feminist theory, and Freirian pedagogy. For example, in a section of the book focused on overcoming barriers to coalition building, Pyles notes that practitioners must de-construct societal narratives that tend to pit groups against each other, arguing that a critical-social constructionist framework can help practitioners overcome "the divide and conquer" narrative. Houston (2008) has advocated the use of critical and postmodern social theory for social workers to understand identity formation in a new way, specifically using the example of working with communities to transcend ethnoreligious identities in Northern Ireland.

\section{CONCLUSION}

A systematic method of investigation is necessary to provide rigor to one's inquiry. However, at the same time, the method circumscribes the type of questions that can be asked, and thus the truths that can be uncovered. While valuable scientific knowledge continues to be produced by social work academics and consumed by social work practitioners, when it comes to knowledge gathering methods (i.e. research), is it truly in the best interest of our profession to limit ourselves to only teaching the scientific method (whether qualitative or quantitative) in research courses? Do we wish to continue to propagate the myth of a false choice between science and ignorance (Drake \& JonsonReid, 2007; Rubin \& Babbie, 2005). One does not need to abandon science in order to embrace other legitimate methods of inquiry. ${ }^{8}$ It is time to expand our conception of "research" when teaching research courses and embrace the humanist base of our profession and the rich traditions in methods of inquiry that it has to offer. This article has described the basic principles of the dialectic method, and has briefly outlined its relevance as a method of inquiry to drive postmodern and critical practice approaches that embrace empowerment, personal agency, and the human spirit-uncovering truths in these areas that lie outside the grasp of scientific inquiry.

The scientific method's form of inquiry is bounded by the proposition of a subjectobject dichotomy: subjects (i.e., observers) seek to accurately perceive objects (entities). Within this proposition, truth exists "out there" in the object of study and must be discovered by the subject. This is why such truth is labeled as objective truth. It lies within the object, independent of the subject. The goal of the subject (observer) is to remain as neutral as possible; any broach of this neutrality interferes with the observer's ability to accurately perceive the truth. As mentioned earlier, the comparative method is also capable of operating within this proposition, guiding historical research and investigative journalism.

The rise of postmodern thought and critical theory has given credence to the long disabused notion of subjective truth. Subjective truth arises when the subject contributes 
to the creation of truth. When operating within the dichotomous subject-object proposition wherein the scientific paradigm lies, subjective truth is not the goal. Subjective truth is seen as objective truth that has been corrupted by bias, and hence, is more personal opinion than truth.

But as was elaborated earlier, Heidegger (1927/1962) advanced a new notion of phenomenology, an hermeneutic phenomenology. The phenomenon (existence plus essence) of investigation (e.g., in social work, the client and his/her life problem) operates hermeneutically. There is a fusion between subject-object rather than a dichotomy. The object (entity) contains the qualities of existence of the phenomenon. The inquiring subjects, via the process of dialogue, socially construct the essence of the phenomenon. Gadamer's (1960/1999) philosophically hermeneutic dialectic method offers a way to rigorously pursue these socially constructed subjective truths - truths that speak to the articulations of identity of the client.

It is hard for these authors to support the argument currently made in research classes - made over the last 50 years if not longer - that, when in the field, the knowledge gained from scientific inquiry is the only legitimate form of truth to guide practice, when it is clear that this is a losing argument to practitioners (Teare \& Sheafor 1995). If armed with a variety of fundamental methods of inquiry, social workers in the field will be better served, greatly expanding the types of questions that they can ask-and thus the scope of truths that they are able to rigorously investigate.

\section{References}

Abbott, H. P. (2002). The Cambridge introduction to narrative. Cambridge: Cambridge University Press.

Alinsky, S. (1971). Rules for radicals: A practical primer for realistic radicals. New York: Random House.

Anderson, H., \& Goolishian, H. (1992). The client is the expert: A not-knowing approach to therapy. In S. McNamee \& K. J. Gergen (Eds.), Therapy as social construction (pp. 25-39). London: Sage.

Au, W. (2007). Epistemology of the oppressed: The dialectics of Paulo Freire's theory of knowledge. Journal for Critical Education Policy Studies, 5(2). Retrieved from: http://www.jceps.com/index.php?pageID=article\&articleID $=100$

Blackburn, S. (1994). “Hegel, Georg Wilhelm Friedrich,” in Oxford dictionary of philosophy (pp. 168-169). Oxford: Oxford University Press.

Blundo, R. (2006). Shifting our habits of mind: Learning to practice from a strengths perspective. In D. Saleebey (Ed.), The strengths perspective in social work practice ( $4^{\text {th }}$ ed., pp. 25-45). Boston: Pearson/Allyn \& Bacon.

Brubaker, S. J., \& Wright, C. (2006). Identity transformation and family caregiving: Narratives of African American teen mothers. Journal of Marriage and Family, 68, 1214-1228. doi: 10.1111/j.1741-3737.2006.00324 
Bruner, J. (1986). Actual minds, possible worlds. Cambridge, MA: Harvard University Press.

De Jong, P., \& Berg, I. K. (2008). Interviewing for solutions ( $3^{\text {rd }}$ ed.). Belmont, CA: Thomson Brooks/Cole.

Drake, B., \& Jonson-Reid, M. (2007). Social work research methods: From conceptualization to dissemination. Boston: Allyn \& Bacon.

Dybicz, P. (2010a). Mimesis: Linking postmodern theory to human behavior. Journal of Social Work Education, 46(3), 341-355. DOI: 10.517S/JSWE.2010.200900072.

Dybicz, P. (2010b). The role of science in postmodern practice. Advances in Social Work, $11,95-116$.

Engel, R., \& Schutt, R., (2010). Fundamentals of social work research. Thousand Oaks, CA: Sage Publications.

Fischer, J. (1973). Is casework effective? A review. Social Work, 18(1) 5-20.

Fischer, J. (1981). The social work revolution. Social Work, 26, 199-207.

Flexner, A. (1915). Is social work a profession? Proceedings of the National Conference on Charities and Correction (pp. 576-590). Chicago: The Hildeman Company.

Freire, P. (1970). Pedagogy of the oppressed. New York: Seabury Press.

Gadamer, H. G. (1999). Truth and method ( $2^{\text {nd }}$ ed.). (J. Weinsheimer \& D. G. Marshall Trans.). New York: The Continuum Publishing Company. (Original work published 1960).

Gadotti, M. (1994). Reading Paulo Freire: His life and work. Albany, NY: State University of New York Press.

Gambrill, E. (2006). Social work practice: A critical thinker's guide ( $2^{\text {nd }}$ ed.). New York: Oxford University Press.

Grinnell, R. M., \& Unrau, Y. A. (2011). Social work research and evaluation: Foundations of evidence-based practice. New York: Oxford University Press.

Hegel, G. W. F. (1991). The encyclopedia logic. (T. F. Geraets Trans). Indianapolis: Hackett Publishing. (Original work published 1830).

Heidegger, M. (1962). Being and time. (J. Macquarrie and E. Robinson Trans.). New York: Harper and Row. (Original work published 1927).

Hepworth, D., Rooney, R., \& Larsen, J. A. (2009). Direct social work practice: Theory and skills ( $8^{\text {th }}$ ed.). Pacific Grove, CA: Brooks/Cole.

Horkheimer, M. (1982). Critical theory. New York: Seabury Press.

Houston, S. (2008). Transcending ethnoreligious identities in Northern Ireland: Social work's role in the struggle for recognition. Australian Social Work, 61(1), 25-41. DOI: $10.1080 / 03124070701818716$ 
Husserl, E. G. A. (1982). Ideas pertaining to a pure phenomenology and to a phenomenological philosophy-first book: General introduction to a pure phenomenology (F. Kersten, Trans.). The Hague: Nijoff. (Original work published 1913).

Jay, M. (1996). The dialectical imagination: A history of the Frankfurt School and the Institute of Social Research, 1923-1950. Berkley: University of California Press.

Johnson, L., \& Yanca, S. (2009). Social work practice: A generalist approach $\left(10^{\text {th }} \mathrm{ed}\right.$.). Boston: Allyn \& Bacon.

Kaufman, W. (1988). Hegel: A reinterpretation. South Bend, IN: University of Notre Dame Press.

Kaufman, C. (2003). Ideas for action: Relevant theory for social change. Cambridge, MA: South End Press.

Kretzmann, J. P., \& McKnight, J. L. (1997). Building communities from the inside out: A path toward finding and mobilizing a community's assets. Skokie, IL: ACTA Publications.

Leighninger, L. (1987). Social work: Search for identity. New York: Greenwood Press.

Leighninger, L. (2000). Creating a new profession: The beginnings of social work education in the United States. Alexandria, VA: Council on Social Work Education.

Leonard, P. (1997). Postmodern welfare: Reconstructing an emancipatory project. London: Sage.

Lincoln, Y. S., \& Guba, E. G. (1985). Naturalistic inquiry. Newbury Park, CA: Sage.

Lindlof, T. R., \& Taylor, B. C. (2002). Qualitative communication research methods $\left(2^{\text {nd }}\right.$ ed.). Thousand Oaks, CA: Sage

McAvoy, M. (1999). The profession of ignorance: With constant reference to Socrates. Lanham, NY: University Press of America.

McTaggart, R. (1997). Guiding principles for Participatory Action Research. In R. McTaggart (Ed.), Participatory Action Research: International contexts and consequences (pp. 25-43). Albany, NY: State University of New York Press.

Pyles, L. (2009). Progressive community organizing: A critical approach for a globalizing world. New York: Routledge.

Rapp, C., \& Goscha, R. (2006). The strengths model: Case management with people with psychiatric disabilities ( $2^{\text {nd }}$ ed.). New York: Oxford University Press.

Ricœur, P., (1984-88). Time and narrative (vol. 1-3). Chicago: University of Chicago Press.

Rodwell, M. (1998). Social work constructivist research. New York, NY: Garland.

Royse, D., Thyer, B. A., \& Padgett, D. (2009). Program evaluation: An introduction (5 ${ }^{\text {th }}$ ed.). Belmont, CA: Wadsworth. 
Rubin, A., \& Babbie, E. (2005). Research methods for social work ( $5^{\text {th }}$ ed.). Belmont, CA: Thomson.

Saleebey, D. (Ed.) (2006a). The strengths perspective in social work practice ( $4^{\text {th }} \mathrm{ed}$.). Boston: Pearson/Allyn \& Bacon.

Saleebey, D. (2006b). Community development, neighborhood empowerment, and individual resilience. In D. Saleebey (Ed.), The strengths perspective in social work practice ( $4^{\text {th }}$ ed., pp. 241- 260). Boston: Pearson/Allyn \& Bacon.

Specht, H., \& Courtney, M. E. (1995). Unfaithful angels: How social work has abandoned its mission. New York: Free Press.

Teare, R., \& Sheafor, B. (1995). Practice-sensitive social work education: An empirical analysis of social work practice and practitioners. Alexandria, VA: Council on Social Work Education.

Trattner, W. I. (1999). From poor law to welfare state: A history of social welfare in America (6 $6^{\text {th }}$ ed.). New York: The Free Press.

Tsang, N. M. (2000). Dialectics in social work. International Social Work, 43(4), 421434. DOI:10.1177/002087280004300402

Turner, J., \& Jaco, R. M. (1996). Problem solving theory and social work treatment. In .J. Turner (Ed.) Social work treatment: Interlocking theoretical approaches $\left(4^{\text {th }}\right.$ ed., pp. 503-22). New York: The Free Press.

Wakefield, J. C., \& Kirk, S.A. (1996). Unscientific thinking about scientific practice: Evaluating the scientist-practitioner model. Social Work Research, 20(2), 83-96.

White, M. (2007). Maps of narrative practice. New York: W. W. Norton \& Co.

White, M., \& Epston, D. (1990). Narrative means to therapeutic ends. New York: Norton.

Witkin, S. L. (1996). If empirical practice is the answer, then what is the question? Social Work Research, 20(2), 69-76.

\section{Author note:}

Address correspondence to: Phillip Dybicz, Keimyung University, Department of Social Welfare, College of Social Science Building, 2800 Dalgubeoldaero, Dalseo-Gu, Daegu 704-701, South Korea. Email: pdybicz@gmail.com 


\section{Endnotes}

${ }^{1}$ For an extended treatment on the role that science plays in postmodern practice see Dybicz (2010b).

${ }^{2}$ This represents a history of the dialectic method in Western philosophical traditions. Yet the dialectic method has also arisen in both Hindu and Buddhist philosophical traditions as well.

${ }^{3}$ Hegel himself did not use the terms thesis-antithesis-synthesis to describe his approach, yet it is this formulation that is popularly used to describe his method (Kaufman, 1988). Hegel's dialectical pattern brings to fore contradictions and self-consciousness that are eventually resolved, though leading to and revealing new contradictions. Importantly, each progressive stage of the dialectic “sublates" the previous stage, which means for Hegel not only a moving on or overcoming of the previous stage, but a retaining of what was in the previous stage (Hegel, 1830/1991).

${ }^{4}$ The point of Marx's materialist dialectics is to understand the interrelated processes transpiring in the material world and provide a space for intervention in those processes to improve the material world (Au, 2007). Marx believed that the dialectic played itself out historically through class conflict such as through the working class and ownership class, eventually resolving itself in a revolution of the working class through socialism and communism.

${ }^{5}$ This definition distinguishes critical theory from modernist, normative theory which seeks to simply explain and predict human behavior. Critical theorists from the Frankfurt school argued that critical theory involves practical application in a moral or value-laden sense, as opposed to normative theory which seeks practical application in an instrumental sense (Horkheimer 1993).

${ }^{6}$ So to summarize, Hegel's work represents dialectical inquiry as philosophical idealism. Marx's work represents dialectical inquiry as philosophical materialism. And Gadamer's work represents dialectical inquiry as philosophical hermeneutics.

${ }^{7}$ While it is always important within the social worker-client relationship to maintain awareness of the power differential arising from the social worker's authority, postmodern practitioners emphasize that the dialogue driving the dialectical inquiry should be entered into in the spirit of equals (De Jong \& Berg, 2008; Saleebey 2006b; White, 2007). They seek to capture this equality through emphasizing collaboration and adopting the stance that the client is the expert.

${ }^{8}$ In recent years, naturalistic inquiry (Lincoln \& Guba, 1985), constructivist research (Rodwell, 1998) and participatory action research (McTaggart, 1997) all represent attempts to incorporate postmodern insights into the development of new types of investigations. While certainly representing worthy endeavors, they generally consider themselves as types of scientific research. They seek to broaden the scope of the scientific method, not leave the scientific paradigm completely. 